\title{
Oxidation of Sulphites by Electrodes Made of Novel Materials for Use in Microbial Fuel Cells
}

\author{
Pchelarov $\mathbf{G}^{1 *}$, Uzun $\mathrm{D}^{1}$, Rikazova Velkova $\mathrm{E}^{\mathbf{2}}$ and Petrov $\mathrm{K}^{\mathbf{1}}$ \\ ${ }^{1}$ Institute of Electrochemistry and Energy Systems, Bulgarian Academy of Sciences, Bulgaria \\ ${ }^{2}$ Institute of Chemical Engineering, Bulgarian Academy of Sciences, Bulgaria \\ *Corresponding author: Pchelarov G, Institute of Electrochemistry and Energy Systems, Bulgarian Academy of Sciences, \\ Bulgaria
}

\begin{tabular}{|c|c|}
\hline ARTICLE INFO & ABSTRACT \\
\hline Received: March 06, 2020 & Catalysts based on novel carbon forms (Fullerenes C60/C70, Higher Fullerenes \\
\hline Published: March 16, 2020 & $\begin{array}{l}\text { and Double Wall Carbon Nanotubes) were applied to facilitate the process of oxidation } \\
\text { of sulfites to sulfates. The electrodes with incorporated new catalysts are able to }\end{array}$ \\
\hline $\begin{array}{l}\text { Citation: Pchelarov G, Uzun D, Rikaz } \\
\text { Velkova E, Petrov K. Oxidation of Sulph } \\
\text { by Electrodes Made of Novel Materials }\end{array}$ & $\begin{array}{l}\text { included steady state polarization curve analysis. The electrodes that incorporate } \\
\text { fullerene structures were found to yield the highest current densities. A short overview } \\
\text { considers the existing sulfur oxidizing microbes that should facilitate the creation of a } \\
\text { workable microbial fuel cell. }\end{array}$ \\
\hline
\end{tabular}

Tech Res 26(4)-2020. BJSTR. MS ID.004381.

Keywords: Electrocatalysts; Fullerenes C60/C70; Higher Fullerenes; DWCNTs, Sodium Sulfite; Sulfate; desulphurization

\section{Introduction}

The removal of pollutants while simultaneously generating energy will help safeguard the environment and enable the development of innovative fuel cells. In this regard a principle objective is to build new electrodes and catalysts able to remove toxic pollutants comprised of such sulphur compounds. Sulfide $\left(\mathrm{H}_{2} \mathrm{~S} / \mathrm{HS}^{-}\right)$and sulphur can be oxidized by microorganisms to yield surplus energy. In marine environments the Sulfur Oxidizing Microorganisms (SOM) are located across the top sediment layers, where oxygen and nitrate, as electron acceptors are readily available. The best studied SOB are in the family Thiobacilliaceae in terrestrial environments and the family Beggiatoaceae (Gammaproteobacteria) in aquatic environments [1]. There exist two routes in sulfite $\left(\mathrm{SO}_{3}{ }^{2-}\right)$ oxidation: (i) by rDsr employed by some microorganisms such as Chlorobi (green sulfur bacteria), Alpha, Beta and Gammaproteobacteria, where sulfide is oxidized to sulfite through sulfite reduction by Dsr. The sulfite generated by rDsr is then oxidized to sulfate by other enzymes [2]; (ii) oxidation of sulfite to sulfate by a mononuclear molybdenum enzyme known as sulfite oxidoreductase [3]. In bac- terial sulfate reduction, bacteria respire sulfate and yield sulfide. The process consists of four paths [4,5]. It has been shown that organotrophic bacteria are capable of the oxidation of thiosulfate to tetrathionate (these bacteria are referred to as T-HSOB) and are found in the redox layer of the Black Sea [6].

Microbial Fuel Cells (MFCs) with graphite anodes and graphite cathodes were built in an aerobic seawater environment and in anoxic marine sediment [7]. The anode electrode was embedded in anoxic marine sediments while connected through electronic circuits to a similar electrode in the overlying aerobic seawater (the cathode), thus building a MFC. The MFC had a power yield of $0.01 \mathrm{~W} / \mathrm{m}^{2}$ and can supply electronic instrumentation [8]. The enrichment with microorganisms from the family Geobacteraceae on graphite anodes allowed these microorganisms to conserve energy, supporting their growth by oxidation of organic compounds with an electrode that served as the electron acceptor [9]. Advanced catalyst supports including carbon nanotubes, aerogels and graphene have been tested in the past [10]. Applied also in catalyst synthesis is a method to fabricate the electro-catalyst for the electrodes using 
a lyophilization process [11]. Key sources when describing the electrochemical oxidation of sulphites in alkaline solutions are [12,13].

These researchers showed that the anodic oxidation of sulphite irreversibly yields sulphate and dithionate. The oxidation of $\mathrm{SO}_{3}{ }^{2-}$ at the anode was found to initiate at $1.2 \mathrm{~V}$ vs SHE in alkaline solutions. $\mathrm{An}^{\mathrm{OH}^{-}}$radical is added to the sulphite ion at relatively high potentials. The anodic oxidation of sulphite ions under alkaline conditions has been studied comprehensively by J Lu et al. [14]. The adsorbed species suffer deprotonation at $\mathrm{pH}<7$ and are then subject to oxidation. In solution, sulphite exists in the form $\mathrm{HSO}_{3}$ and $\mathrm{SO}_{3}{ }^{2-}$ with the following equilibria between these species [15]:

$$
\begin{gathered}
\mathrm{SO}_{2}(\mathrm{aq})+\mathrm{H}_{2} \mathrm{O}=\mathrm{HSO}_{3}{ }^{-}+\mathrm{H}^{-} \\
\mathrm{HSO}_{3}^{-}+\mathrm{H}_{2} \mathrm{O}=\mathrm{SO}_{3}{ }^{2-}+\mathrm{H}
\end{gathered}
$$

$\mathrm{SO}_{2}(\mathrm{aq}), \mathrm{HSO}_{3}{ }^{-}$and $\mathrm{SO}_{3}{ }^{2-}$ species are predicted to predominate over the $\mathrm{pH}$ ranges $<1.8,1.8-7$ and $>7$, respectively. At $\mathrm{pH}>12$, the dominant species in solution is $\mathrm{SO}_{3}{ }^{2-}$. Novel electro-catalytic materials such as higher fullerenes and carbon nanotubes are studied in our current research. Higher fullerenes are fabricated by applying the carbon arc method in a quartz reactor followed by sublimation. These include the fairly stable species $\mathrm{C}_{74}, \mathrm{C}_{78}, \mathrm{C}_{80}, \mathrm{C}_{82}, \mathrm{C}_{84}, \mathrm{C}_{86}, \mathrm{C}_{88}$, $\mathrm{C}_{90}, \mathrm{C}_{92}, \mathrm{C}_{94}, \mathrm{C}_{96}, \mathrm{C}_{98}, \mathrm{C}_{100}$. Characteristic of higher fullerenes is that the bonding sites between the pentagon atom groups are usually found to be the most reactive.

\section{Materials and Methods}

In this study, we use "higher fullerenes", made by the method of Deener and Alford, also called "narrow gap fullerenes" [16]. Sodium sulfite $\left(\mathrm{Na}_{2} \mathrm{SO}_{3}\right)$, sodium chloride $\mathrm{NaCl}$ and higher order fullerenes were purchased together with manganese acetate and polypyrrole from Sigma Aldrich. Fullerenes $\mathrm{C}_{60} / \mathrm{C}_{70}$ and DWCNTs were pur- chased from CEC Research, Houston, Texas. The Vulkan XC-72 particles with a particle size of $50 \mathrm{~nm}$ were purchased from the Cabot Corporation and prepared in accordance with [17]. The catalysts studied were lyophilized fullerenes $\mathrm{C}_{60} / \mathrm{C}_{70}$, higher fullerenes and DWCNTs (2-11 mg) dispersed in $6 \mathrm{ml}$ of distilled water in an ultrasonic bath for 15 minutes. Subsequently, $40 \mathrm{mg}$ of manganese acetate are slowly added to the aqueous suspension together with 60 mg of polypyrrole. These ternary mixtures were then baked at 180 ${ }^{\circ} \mathrm{C}$ for 12 hours in a Teflon autoclave. Thus, manganese oxides cover the fullerene and nanotube structures with polypyrrole binding. The electrodes under investigation have a geometric area of 1 and $10 \mathrm{~cm}^{2}$. The electrodes were prepared from a catalyst mixture and Teflonized carbon black ( $60 \mathrm{mg} / \mathrm{cm}^{2}$ Vulcan XC-72 (35\% Teflon)) as a binder [18]. The mixture is compressed on both sides of a stainless-steel collector at $150{ }^{\circ} \mathrm{C}$ and pressed at $300 \mathrm{~kg} / \mathrm{cm}^{2}$ (Table 1).

Table 1: Catalyst content incorporated in the electrodes.

\begin{tabular}{|c|c|}
\hline Name & Content \\
\hline MnAFPVT - L & $\begin{array}{c}\text { Manganese acetate + Polypyrrole + } \\
\text { Fullerenes C60/C70 }\end{array}$ \\
\hline MnAHFPVT - L & $\begin{array}{c}\text { Manganese acetate + Polypyrrole + } \\
\text { Higher Fullerenes }\end{array}$ \\
\hline MnAHFPDWCNTVT - L & $\begin{array}{c}\text { Manganese acetate + Polypyrrole + } \\
\text { Higher Fullerenes + DWCNTs }\end{array}$ \\
\hline \multicolumn{2}{|c|}{ L -Lyophilized catalyst; } \\
All the catalyst contain TV35 - (60 mg Vulcan XC 72 + 35\% Teflon) \\
\hline
\end{tabular}

\section{Results/Observations}

\section{XRD Analysis}

Shown in Figure 1 is an XRD of the catalyst incorporating higher fullerenes and manganese oxides.

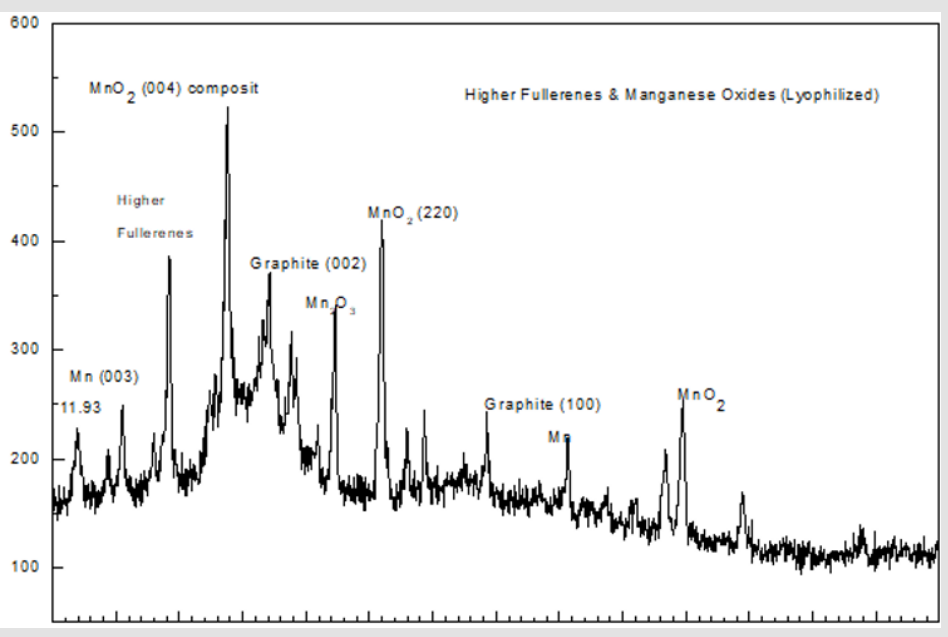

Figure 1: XRD of lyophilized higher fullerenes and manganese oxides. 


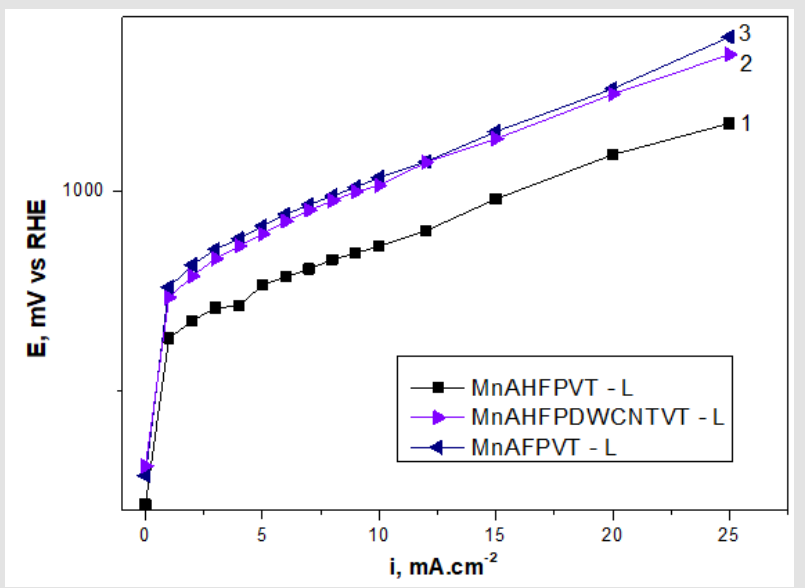

Figure 2: Comparison of the best catalysts incorporated in the electrodes with the corresponding potentials and current density during sulphite oxidation: 1- (MnAHFPVT - L); 2 - (MnAHFPDWCNTVT - L); 3 - (MnAFPVT - L); (at $150{ }^{\circ} \mathrm{C}$ and P = 0.3 mbar). Electrolyte: $1 \mathrm{M} \mathrm{Na}_{2} \mathrm{SO}_{3}+18 \mathrm{mg} / 1 \mathrm{NaCl}, \mathrm{t}=20^{\circ} \mathrm{C}$.

\section{Polarization Curve Analysis}

Shown in Figure 2 are the polarization curves of the electrodes having the best characteristics. The lowest overpotentials were observed in electrodes containing higher order fullerenes (MnAHFPVT-L). The least efficient electrodes incorporate the most common and abundant fullerenes $\mathrm{C}_{60} / \mathrm{C}_{70}$ (MnAFPVT-L). We assume that the higher performance of fullerenes is probably due to the higher number of pentagons forming their grids, which leads to a higher catalytic activity. The closed caps of the doublewall carbon nanotubes are of a fullerene nature being comprised of pentagons. All the catalysts contain the same amounts of manganese oxides.

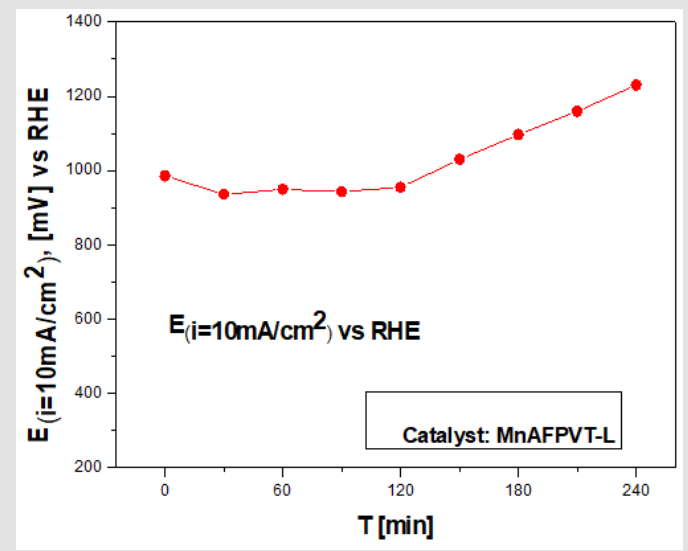

Figure 3: Dependence of the anode potential at constant current density with time. The electrode incorporates the catalyst [MnAFPVT - L] - $\left(10 \mathrm{~cm}^{2}\right)$. Electrolyte $1 \mathrm{M} \mathrm{Na}_{2} \mathrm{SO}_{3}-132 \mathrm{~g} / 1+18 \mathrm{~g} / 1 \mathrm{NaCl}$.

Dependence of The Anode Potential with Time at Con-

\section{stant Current Density}

In order to verify the effectiveness of the new sulfite oxidation of the catalysts utilized, electrodes having an area of $10 \mathrm{~cm}^{2}$ were built. The work electrode incorporates the catalyst [MnAFPVT - L] $\left(10 \mathrm{~cm}^{2}\right)$. The catalyst is lyophilized. A gas diffusion electrode as described was mounted as the counter electrode [19]. The reference electrode RHE is from Gaskatel. The compound system $\mathrm{Na}_{2} \mathrm{SO}_{3} / \mathrm{O}_{2}$ was employed for this purpose, where the concentration of $\mathrm{Na}_{2} \mathrm{SO}_{3}$ was monitored following its conversion acting as a fuel in the electrochemical cell. The concentration of sulfite was determined iodometrically using starch as an indicator [20]. From the electrochemical measurements and analytical tests presented in Table 2 and plotted in Figure 3 it is evident, that the electrode incorporating the catalyst MnAFPVT - L, is able to convert a sizable amount of the sulfite in the course of 2 hours. We should note that the decrease in sulphite concentration is not stoichiometric. After four hours, when 
the electrochemical process comes to a halt the sulfite ions continue to decrease and no poisoning of the electrode is observed.

Heeding the results presented in Figure 3 and in Table 2 we can conclude, that it is possible to build electrochemical cells fuelled by electrolytes such as: $\mathrm{Na}_{2} \mathrm{SO}_{3} / \mathrm{O}_{2} ; \mathrm{SO}_{2} / \mathrm{O}_{2} ; \mathrm{SO}_{3} / \mathrm{NO}_{3}$ that may be used to decontaminate natural and industrial pollutants while at the same obtaining surplus energy [19]. In our future work we envisage the application of the bacteria Beggiatoaceae (Gammaproteobacteria), Alpha, Beta and Gammaproteobacteria, T-HSOB, sulfite reduction by Dsr and others in the test fuel cell, to successful build an effective MFC.

Table 2: Experimental data of the decrease of the sulfite concentration with time at $\mathrm{i}=10 \mathrm{~mA} \cdot \mathrm{cm}^{-2}$.

\begin{tabular}{|c|c|}
\hline Time [min.] & $\begin{array}{c}\text { Sulfite concentration [mg/l] } \\
\text { Catalyst: } \\
\text { [MnAPFVT }- \text { L] }\end{array}$ \\
\hline 0 & 132 \\
\hline 120 & 112,6 \\
\hline 240 & 90 \\
\hline
\end{tabular}

\section{Acknowledgement}

This work was supported by the project "New fuel cells based on chemical and microbial processes", through the Ministry of Education and Science and the Bulgarian National Science Research Fund, contract DFNI E02/15. In addition we acknowledge with deep gratitude the help of Prof. R. Stoyanova from the Institute of Inorganic Chemistry for affording us the opportunity to utilize the lyophilisation apparatus at the institute.

\section{References}

1. Fike DA, Bradley AS, Leavitt WD (2016) Geomicrobiology of sulfur (Sixth edn.). Ehrlich's Geomicrobiology.

2. Grimm F, Franz B, Dahl C (2008) Thiosulfate and sulfur oxidation in purple sulfur bacteria. Microbial Sulfur Metabolism. Springer 101-116.

3. Kappler U, Dahl C (2001) Enzymology and molecular biology of prokaryotic sulfite oxidation. FEMS Microbiology Letters 203 (1): 1-9.
4. Rees CE (1973) A steady-state model for sulphur isotope fractionation in bacterial reduction processes. Geochim Cos mochim Acta 37(5): 11411162.

5. Canfield DE (2001) Biogeochemistry of sulfur isotopes. In Reviews in Mineralogy and Geochemistry 43(1): 607-636.

6. Tuttle JH, Schwartz JH, Whiled GM (1983) Some Properties of Thiosulfate-Oxidizing Enzyme from Marine Heterotroph 16 B. Appl Environ Microbiol 46(2): 438-445.

7. Schievano A, Colombo A, Grattieri M, Trasatti SP, Liberale A, et al. (2017) Floating microbial fuel cells as energy harvesters for signal transmission from natural water bodies. J. Power Sources 340: 80-88.

8. Reimers CE, Tender LM, Fertigg S, Wang W (2001) Environ Sci Technol 35: 192-195.

9. Bond DR, Holmes DE, Tender LM, Lovley DR (2002) Science 295: 483 485 .

10. Antolini E (2012) Graphene as a new carbon support for lowtemperature fuel cell catalysts. Appl Catal B 123-124: 52-68.

11. Wu ZS, Sun Y, Tan YZ, Yang SB, Feng XL, et al. (2012) Three-Dimensional Graphene-Based Macro- and Mesoporous Frameworks for HighPerformance Electrochemical Capacitive Energy Storage. J Am Chem Soc 134: 9082-9085

12. Zhdanov SI (1975) Encyclopedia of the Electrochemistry of the Elements Vol 4.

13. Tarasevich MR, Khrushcheva (1989) Modern Aspects of Electrochemistry. No 1 9295-359.

14. Lu J, Dreisinger DB and Cooper WC (1999) Journal of Applied Electrochemistry 29: 1161-1170.

15. Greenwood NN, A Earnshaw A (1990) Chemistry of the Elements. Pergamon Press 851-853.

16. Diener, Alford JM (1998) Nature (London) 393: 668-671.

17. Ralph TR and Hogarth MP (2002) Plat Met Rev 46(1) 4-15

18. Uzun D, Razkazova Velkov E, Petrov K, BeschkovV (2015) Electrochemical method for energy production from hydrogen sulfide in the Black sea waters in sulfide-driven fuel cell. Bull Chem Comm 47: 92.

19. Enache A F, Dan ML, Vaszilcsin N (2018) Electrochemical Oxidation of Sulphite in Neutral Media on Platinum Anode. Int J Electrochem Sci 13(2018): 4466-4478.

20. Jeffry GH, Baset J, Mandham J, Denney RC (1989) Vogel's Textbook of Quantitative Chemical Analysis. 5th ed Longman Scientific and Technical New York 398-399.
ISSN: 2574-1241

DOI: 10.26717/BJSTR.2020.26.004381

Pchelarov G. Biomed J Sci \& Tech Res

This work is licensed under Creative

Commons Attribution 4.0 License

Submission Link: https://biomedres.us/submit-manuscript.php

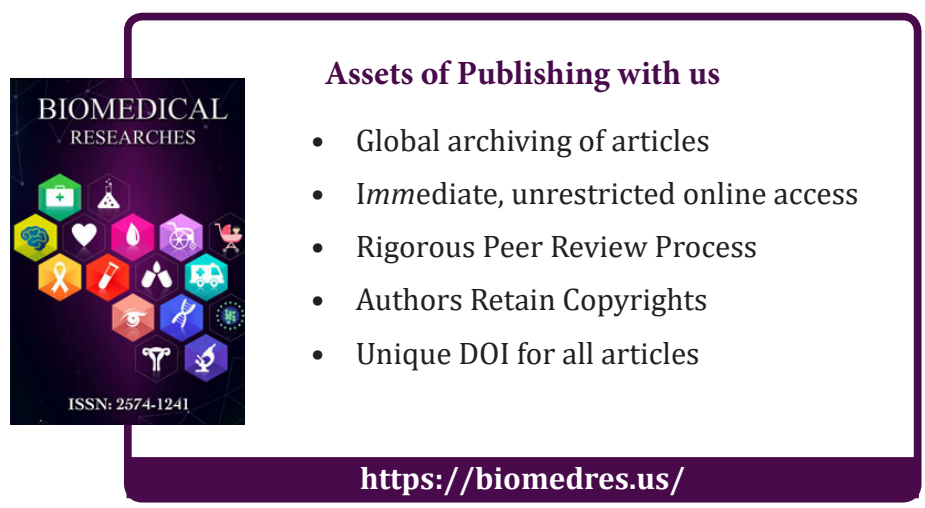

